\title{
ON THE SYSTEMATICS OF THE WATER MITE PIONA NODATA (MÜLLER, 1776) (ACARI: HYDRACHNIDIA, PIONIDAE)
}

\author{
Petr V. Tuzovsky \\ Institute for Biology of Inland Waters, Russian Academy of Sciences, Borok, Yaroslavl Prov., Russia \\ E-mail: tuz@ibiw.yaroslavl.ru
}

\begin{abstract}
The redescription of larva, male and female of the water mite Piona nodata (Müller, 1776) are provided. The larva described under the name $P$. nodata (Wainstein 1976, 1980) was misidentified. The new synonym is established: Piona lacerata Sokolow, 1928=P. nodata (Müller, 1776).
\end{abstract}

KEY WORDS: Water mite, Pionidae, Piona nodata, morphology, larva, male, female.

DOI: 10.21684/0132-8077-2017-25-2-135-142

\section{INTRODUCTION}

The water mite Piona nodata (Müller, 1776) is widespread in the Holarctic (Lundblad 1968, Viets 1978). The larval morphology of $P$. nodata was studied by Sparing (1959) and Wainstein (1976, 1980), while its deutonymph was described by Tuzovskij (1990). The species of the Piona nodata is complex: P. nodata, P. ambigua (Piersig, 1894), $P$. laminata (Thor, 1901) and P. annulata (Thor, 1901) are distinguishable in the females only (Smith et al. 2015, Gerecke et al. 2016). The descriptions of the larva and adult of $P$. nodata are incomplete, which complicates the identification of the species. The larva described under the name $P$. nodata (Wainstein 1976, 1980) was misidentified (see the description below). The aim of the paper is a detailed study of the morphology of $P$. nodata larva, as well as a redescription of male and female of this species, collected in Russia. I also discuss the taxonomic status of Piona lacerata Sokolow, 1928.

\section{MATERIAL AND METHODS}

The material was collected by the author in the European and Asian parts of Russia. To obtain larvae, water mite was maintained in the laboratory under room temperature and natural day-night conditions.

Idiosomal setae are named according to $\mathrm{Tu}-$ zovskij (1987): Fch-frontales chelicerarum, $\mathrm{Fp}$-frontales pedipalporum, $\mathrm{Vi}$-verticales internae, $\mathrm{Ve}$ - verticales externae, $\mathrm{O} i$ - occipitales internae, $\mathrm{Oe}$-occipitales externae, $\mathrm{Hi}$-humerales internae, $\mathrm{He}$-humerales externae, $\mathrm{Hv}$-humeralis ventralia, Sci-scapulares internae, Sce-scapulares externae, $L i$-lumbales internae, $L e$-lumbales externae, $\mathrm{Si}$-sacrales internae, $\mathrm{Se}$ - sacrales externae, $C i$-caudales internae, $P i-$ praeanales internae, $P e$ - praeanales externae, $A i$-anales internae, $A e$ - anales externae.
Furthermore, the following abbreviations are used: P-1-5, pedipalp segments (trochanter, femur, genu, tibia and tarsus); I-Leg-1-5, first leg, segments 1-5 (trochanter, femur, genu, tibia and tarsus) i.e. I-Leg-4=genu of first leg; $\mathrm{C} 1$ - coxal seta located posteromedially on coxa I, C2-coxal seta located posterolaterally on coxa I, C3 - coxal seta located posterolaterally on coxa II, C4 - coxal seta located anteriorly on coxa III, s-solenidion, acacanthoid seta, L — length; W-width; D — diameter; $n=$ number of specimens measured; all measurements are given in micrometers $(\mu \mathrm{m})$.

\section{Family Pionidae Thor, 1900 \\ Genus Piona Koch, 1842 Piona nodata (Müller, 1776)}

Figs. 1-28

\section{Piona nodata var. lacerata Sokolow, 1928, nov. syn.}

Material examined. Russia: 33 females, 16 males and 62 larvae; 12 females, 7 males, Yaroslavl Province, Nekouz District, temporary waters near settlement Borok and village Pogorelka, May-June 2015, 2017; 6 males, 16 females, Samara Province, Stavropol District, National natural Park "Samarskaya Luka", small ponds near village Koltsovo, May-June 1992-1993; 3 males, 5 females, Magadan Province, Anadyr District, small lake near settlement Markovo, June-July 1981. Larvae were reared from seven females, the duration of the embryonic period was $10-15$ days.

Diagnosis. Larva. Dorsal shield convex and elongate, setae $\mathrm{C} 2$ shorter than $\mathrm{C} 3$; excretory pore plate wider than long with convex anterior margin; basal segment of chelicera with reticulation; P-4 with three setae, III-Leg-2 with one, III-Leg-4 with four heavy setae; dorsal shield and all coxal 


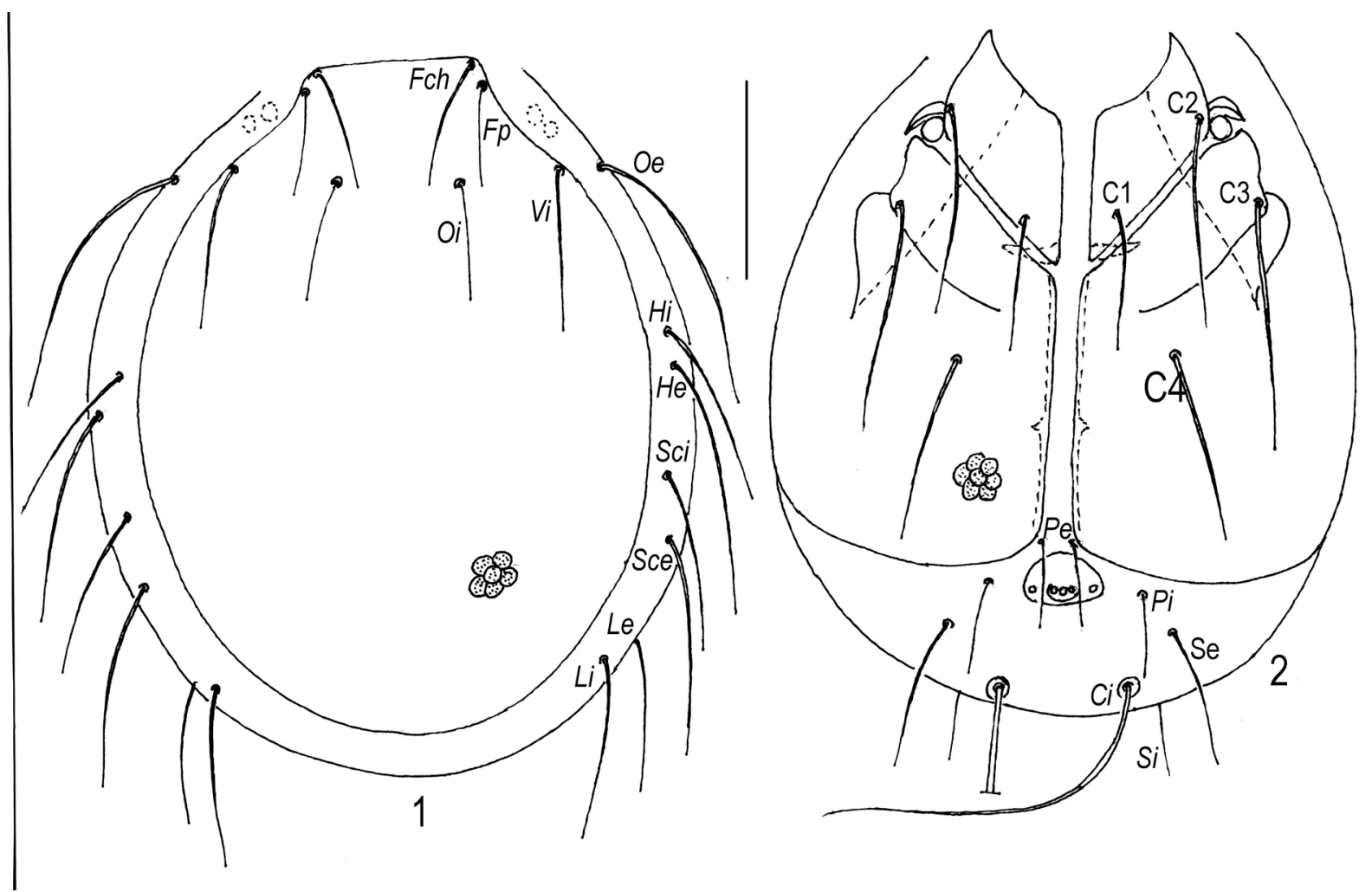

Figs. 1-2. Piona nodata (Müller, 1781), larva: 1—dorsal view; 2-ventral view. Scale bars $100 \mu \mathrm{m}$.

plates porous and with reticulation; adults: dorsum with two elongate narrow plates; setae $F$ ch long, thick; pedipalp comparatively short and compact; P-3 with three setae, lateral setae longest, equal or longer than dorsal margin of segment, P-4 with two distinct ventral setal tubercles, lying behind each other; male: coxal plates IV fused to each other but suture line present, genital field fused to posterior margin of coxal plates IV, with 7-14 pairs of acetabula, ejaculatory complex proximal chamber large, with a curving narrow projection, forming three coils, I/II-Leg-6 distally slightly thickened, I-Leg-5 with 4-7 swimming setae; female: acetabular plates bowed, with 6-14 pairs acetabula, usually one acetabulum in width, I/ II-Leg-6 distally not thickened, I-Leg-5 with 6-10 swimming setae.

Description. Larva. Idiosoma flat, dorsal plate convex and elongate (L/W ratio 1.2-1.6), covering almost the whole dorsum (Fig. 1), bearing four pairs of setae ( $F c h, F p$, $V i, O i$ ) with convex lateral margins, its anterior margin straight or slightly convex, posterior margin rounded; setae Fch slightly shorter than $\mathrm{Vi}$, trichobothria $\mathrm{Fp}$ and $\mathrm{Oi}$ relatively long and equal in length. Setae $\mathrm{Oe}, \mathrm{Hi}$, $\mathrm{He}$, Sci, Sce, Li and Le situated in soft membrane, $\mathrm{Oe}$ longest, $\mathrm{Hi}$ slightly shorter than $\mathrm{He}$, Sce slightly longer than $S c i$, and $L i$ slightly longer than $L e$.
Coxal plates (Fig. 2) moderately large and elongate, first plates with short apodemes directed laterally, plates II-III with single rudimentary apodeme near middle of their medial margin on each side. Setae C1 shorter than C2; C4 relatively thick, not reaching to posterior margin of coxal plates III and shorter than C3. Setae $C i$ very long thickened, located on small tubercles. Setae $P i$ and $P e$ subequal and moderate in length. Excretory pore plate (Figs. $3-5)$ wider than long (L/W ratio 0.5-0.75) with convex anterior margin; bases of setae $\mathrm{Ai}$ and $\mathrm{Ae}$ forming true transverse row and located near posterior margin of the plate, $A e$ slightly longer than $A i$, bases of $A i$ close to each other, located slightly anteriolaterally to excretory pore.

Capitulum (Fig. 6) with wide base and relatively narrow rostrum, anterior hypostomal setae longer than posterior ones. Surface of capitular base with reticulation.

Basal segments of chelicerae (Fig. 7) fused to each other medially, expanded proximally and tapering distally, with reticulation; chela small, pointed (Fig. 8).

Pedipalps short and stocky (Fig. 9): P-1 short and without seta; $\mathrm{P}-2$ large with slightly convex dorsal margin, with single dorsodistal seta; $\mathrm{P}-3$ with very long, thick proximolateral seta and relatively short dorsodistal one; $\mathrm{P}-4$ with three thin 


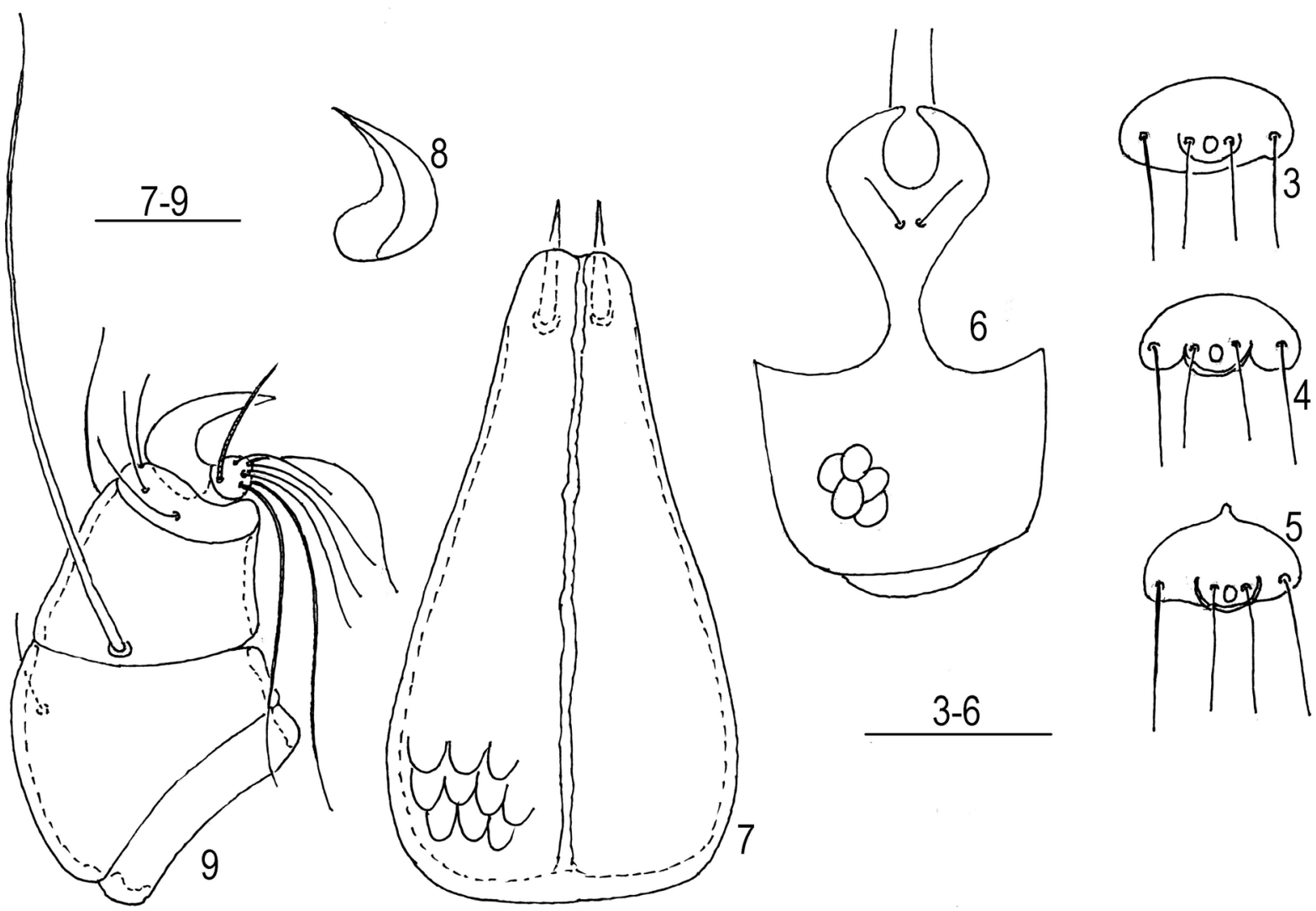

Figs. 3-7. Piona nodata (Müller, 1781), larva: 3-5 excretory pore plate; 6-capitulum, ventral view; 7-chelicera, dorsal view; 8-chela, lateral view; 9-pedipalp, lateral view. Scale bars $50 \mu \mathrm{m}$ (3-6), $20 \mu \mathrm{m}$ (7-9).

setae and large dorsodistal claw; P-5 small, with single solenidion, two long and five relatively short unequal simple setae.

Legs 5 segmented, shape and arrangement of setae on legs segments as shown in Figs. 10-12. Total number of leg setae, excluding eupathidia, as follows (specialized setae indicated in parentheses): I-Leg-1-5: 1, 7, 5 (s), 11 (2s), 14 (s, ac); II-Leg-1-5: 1, 7, 5 (s), 11 (2s), 13 (s, ac); III-Leg-1-5: 1, 6, 5 (s), 10 (s), 11 (ac). Number of thickened distal setae from trochanter to tarsus: I-Leg: $0,1,1,1,0$; II-Leg: 0, 1, 2, 3, 0; III-Leg: 0, 1, 2, 4, 0. I-Leg-1 with relatively short seta, II/III-Leg-1 each with long seta. Solenidion or solenidia on I/II-Leg-3/4 located dorsodistally, solenidion on III-Leg-3/4 and II-Leg-5 located a little dorsodistally to middle of these segments; I/II-Leg-4 with subequal solenidia. Acanthoid seta comparatively short and setose, located distally on tarsus of all legs. Lateral claws and empodial claw nearly equal in length, but lateral claws comparatively thin (Figs. 13-14).

Measurements, $\mathrm{n}=10$. Dorsal plate L 300-350, W 210-250; setae Fch L 45-52, setae Vi L 55-65, setae $F p$ and $O i$ L 40-45; setae L Oe 92-100; setae $\mathrm{Hi}$ and $\mathrm{Sci} \mathrm{L}$ 55-65, setae He and Sce L 70-80, setae $L i$ L 75-80, setae $L e$ and $S e$ L 65-75; setae
$S i$ L 32-39; setae $C i$ L 130-155, setae $P i$ and $P e$ L 48-55; setae $A i$ L 32-38; setae Ae L 40-48; setae C1 L 65-80, setae C2 L 90-103, setae C3 L 108125, setae C4 L 85-96; medial edge of coxa I L 80-90, medial edges of coxae II+III L 140-150; urstigma L 11-13; excretory pore plate L 22-26, W 33-42; cheliceral segments: base L 86-93, chela L 16-19; pedipalpal segments (P-1-5) L: 8-10, 26-36, 31-33, 9-10, 6-7; leg segments L: I-Leg-1-5: 32-40, 38-42, 41-48, 48-52, 65-71; II-Leg-1-5: 37-42, 37-40, 41-48, 64-71, 80-85; III-Leg-1-5: 39-48, 41-45, 44-49, 70-77, 95-105.

Deutonymph. See Tuzovskij (1990).

Adults. Color red to dark brown. Idiosoma oval, integument soft and striated. Dorsum with two relatively long narrow platelets (Fig. 15) often barely visible. All dorsal setae thin and approximately equal in length, but setae $F c h$ (Fig. 16) much longer and thicker than other idiosomal setae associated with glandularia and trichobothria. Anterior coxal groups separated with short apodemes (Fig. 17). Excretory pore surrounded by narrow sclerotizing ring and situated anteriorly to setae $P i$ and $\mathrm{Ci}$. Capitulum with short anchoral process and two pairs of subequal ventral setae. Pedipalp (Fig. 18) relatively short and compact: P-1 with single 


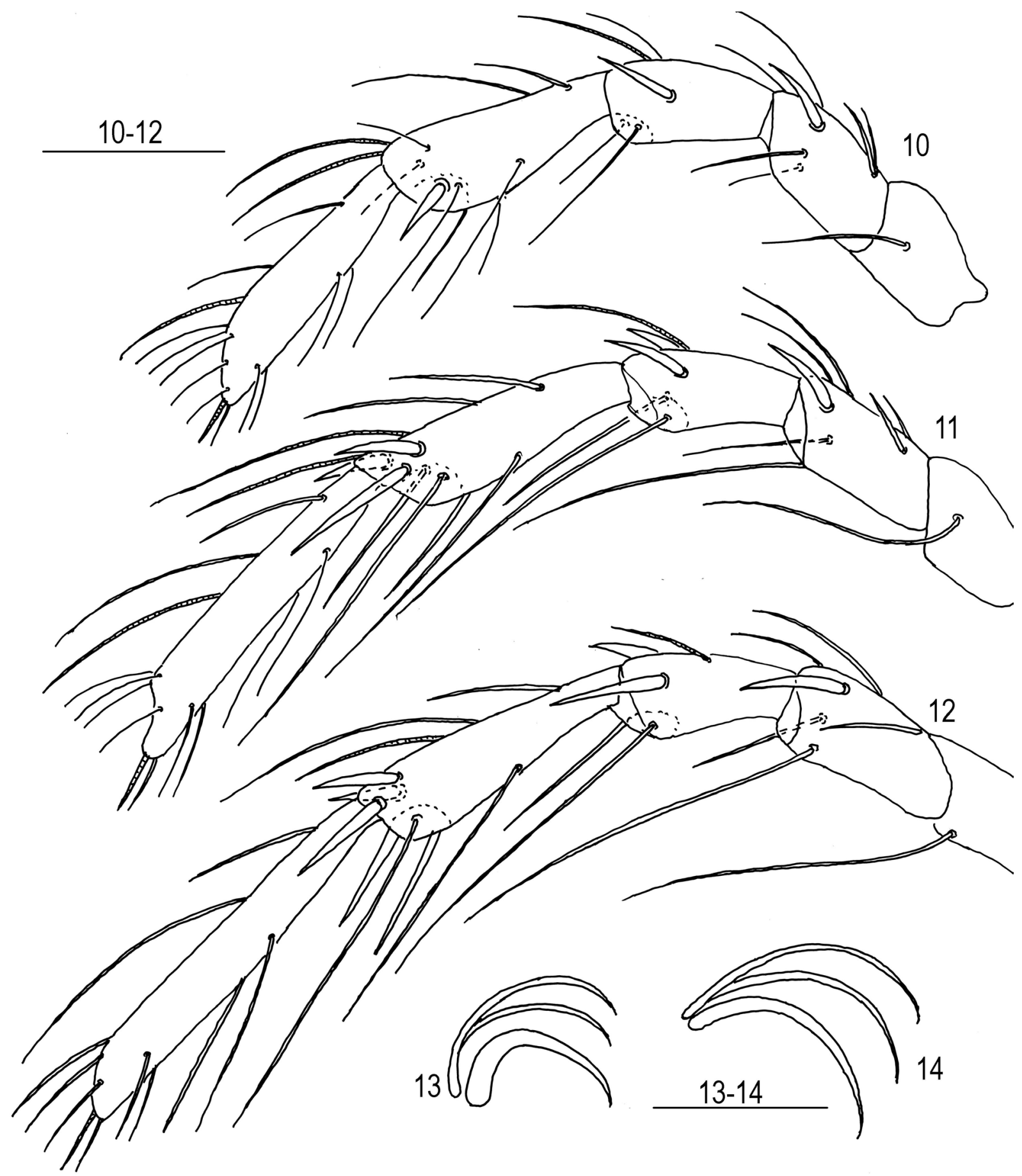

Figs. 10-14. Piona nodata (Müller, 1781), larva: 10-Leg I; 11—Leg II; 12-Leg III; 13—claws of leg I; 14—claws of leg III. Scale bars $50 \mu \mathrm{m}$ (10-12), $20 \mu \mathrm{m}$ (13-14).

short dorsodistal seta; P-2 ventral margin slightly convex with five subequal dorsal setae; P-3 with three unequal setae, lateral seta longest and located proximally to middle of segment; P-4 with two subequal distinct ventral setal tubercles, lying behind each other, ventrodistal peg-like seta relatively large; P-5 moderately long.

Male. Sclerites bearing setae $H v$, fused with posterior of coxal plates II, but suture line present on each side (Fig. 17). Coxal plates III separated, interspace between them sclerotized. Coxal plates IV fused to each medially but suture line present. Acetabular plates fused to posterior margins of coxal plates IV and slightly extending laterally beyond posterior projections of these plates. Gonopore oval to gexagonal in shape, with small median incision anteriorly, genital pit deep, 8-21 subequal genital acetabula on each side, occasionally one to three pairs of acetabula large than other acetabula. Ejaculatory complex (Fig. 19) with long 


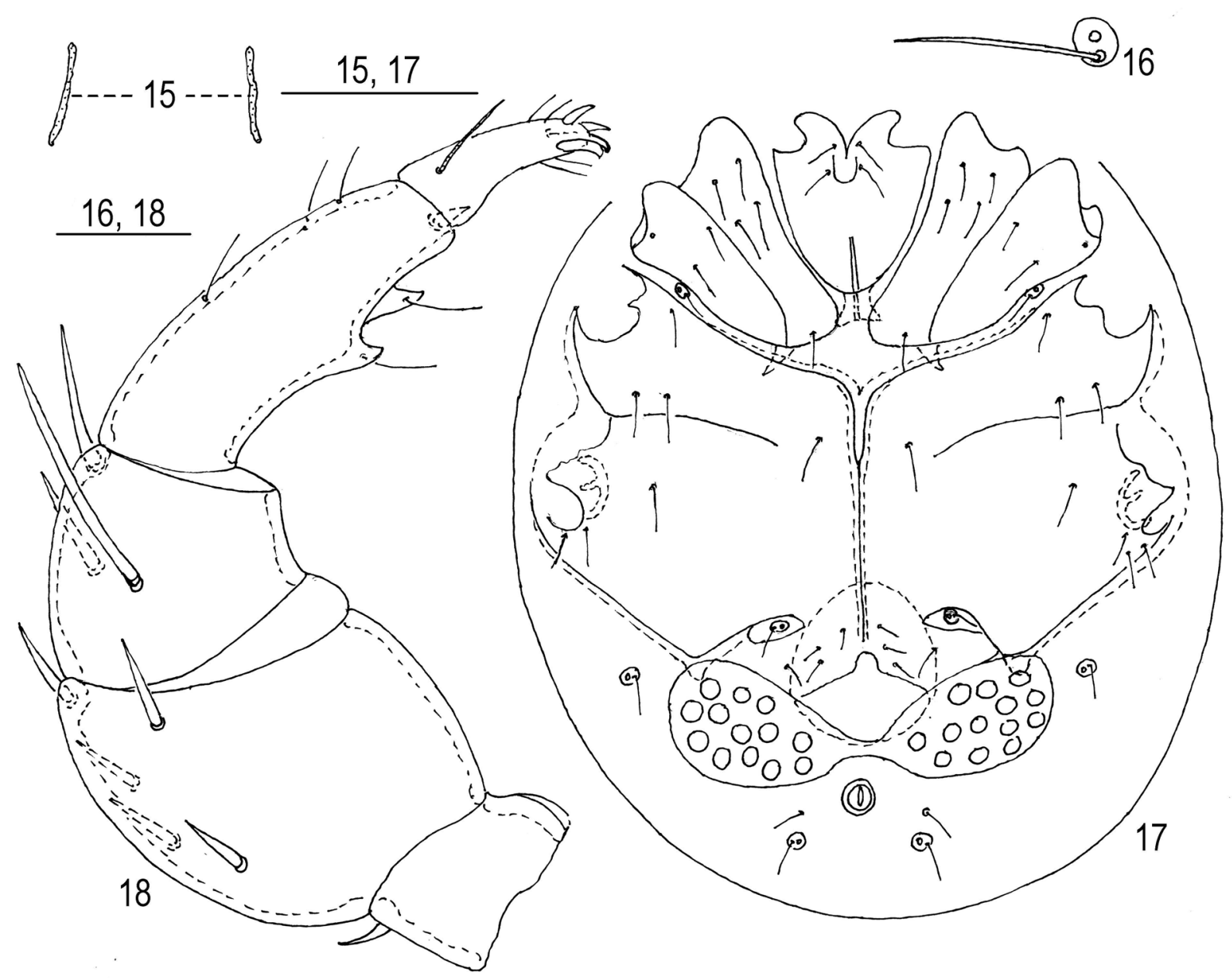

Figs. 15-18. Piona nodata (Müller, 1781), male: 15-dorsal platelets; 16-seta Fch; 17-idiosoma, ventral view; 18 -pedipalp, lateral view. Scale bars $200 \mu \mathrm{m}(15,17), 50 \mu \mathrm{m}(16,18)$.

proximal arms and comparatively short distal arms; proximal chamber large, with a curving narrow proximal projection forming three coils.

I/II-Leg-6 (Fig. 20) distally slightly thickened; III-Leg-4 swimming setae reduced, III-Leg-5 long distally slightly expanded, III-Leg-6 comparatively short and club-shaped (Fig. 21); IV-Leg-4 thick, with a deep concavity bearing numerous unequal spine-like setae, IV-Leg-5 slightly expanded distally, IV-Leg-6 straight thin, with three to five thick setae (Fig. 22). Number of swimming setae as follows: four to five on I-Leg-4, four to seven on ILeg-5; five to eight on II-Leg-4-5; four to seven on III-Leg-5; two to three on IV-Leg-4, 7-12 on IVLeg-5. Claws of tarsi I-II comparatively large, with two long clawlets (Fig. 23). Claws of legs III asymmetrical (Fig. 24); large claw with thick, long straight dorsal clawlet and a thin curved ventral clawlet; small claw with a subequal clawlets.

Measurements $(n=10)$. Idiosoma L 700-940; dorsal plates L 85-115, W 10-15; seta Fch 85-100; cheliceral segments L: base $185-215$, chela $62-75$; pedipalp segments (P-1-5) L: 37-50, 110-140, 65-75, 110-140, 50-62; leg segments L: ILeg-1-6: 75-115, 110-125, 150-190, 185-250, 200-250, 235-290; II-Leg-1-6: 75-115, 110-150, 150-200, 225-275, 210-275, 235-300; IIILeg-1-6: 85-115, 110-165, 130-170, 235-300, 275-325, 175-225; IV-Leg-1-6: 125-150, 125150, 110-150, 190-240, 225-290, 210-275.

Female. All coxal groups (Fig. 25) separated and covering about half of the ventral surface in mature specimens. Medial margin of coxal plate IV 2.0-2.5 times longer than medial margin of coxal plate III. Posterior margins of coxal plates IV forming right or obtuse angles, apodemes moderately developed. Genital field with two bowed plates bearing 6-14 acetabula usually in a single row embracing one or two other acetabula which located in the soft integument or fused to the medial acetabular plate margin (Fig. 26). Each acetabular plate with three to five anterior and two to three posterior genital setae. Acetabula and genital setae usually located on acetabular plates but occasionally one to 

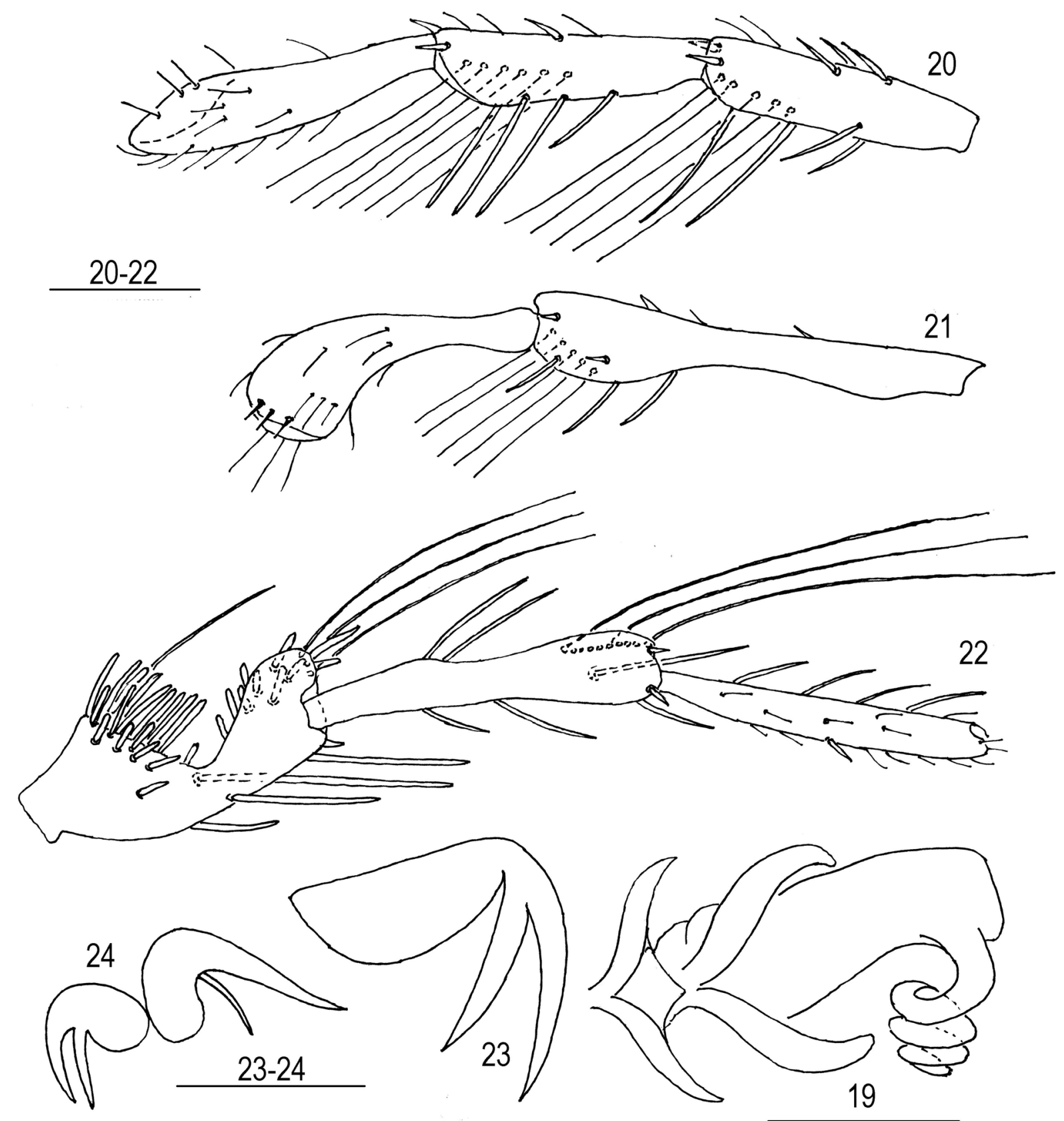

Figs. 19-24. Piona nodata (Müller, 1781), male: 19 - ejaculatory complex; 20-I-Leg-4-6; 21-III-Leg-5-6; 22-IVLeg-4-6; 23 — claw of leg I; 24 — claws of leg III. Scale bars $100 \mu \mathrm{m}(19,20), 50 \mu \mathrm{m}(23-24)$.

three anterior acetabula and genital setae situated on soft integument (Figs. 27-28). Legs thin and slender, I/II-Leg-6 not thickened. Number of swimming setae as follows: 5-6 on I-Leg-4, 6-10 on I-Leg-5; 8-11 on II-Leg-4/5; 9-10 on III-Leg-4; 10-12 on III-Leg-5; 7-9 on IV-Leg-4/5.

Measurements $(\mathrm{n}=10)$. Idiosoma L 800-1,350; dorsal plates L 75-100, W 8-15; seta Fch 100-115; cheliceral segments L: base 200-260, chela 62-75; pedipalp segments (P-1-5) L: 37-50, 125-150, 62-90, 110-137, 50-75; leg segments L: ILeg-1-6: 85-100, 125-150, 175-215, 250-290, 250-325, 275-340; II-Leg-1-6: 90-100, 135-165,
200-240, 260-340, 275-340, 285-350; IIILeg-1-6: 90-115, 135-175, 185-240, 275-340, 285-350, 285-350; IV-Leg-1-6: 150-190, 160190, 210-250, 285-340, 285-375, 275-325.

Remarks. The morphology of the present larva and the larva described by Wainstein (1980) under the name P. nodata (Müller, 1781) is with essential differences. The following clear differences can be found in the morphology of the larva of $P$. nodata (character states of larva $P$. nodata are given in parenthesis after Wainstein 1980): setae C2 shorter than C3, Fig. 2 (much longer than C3); excretory pore plate with convex anterior margin, 


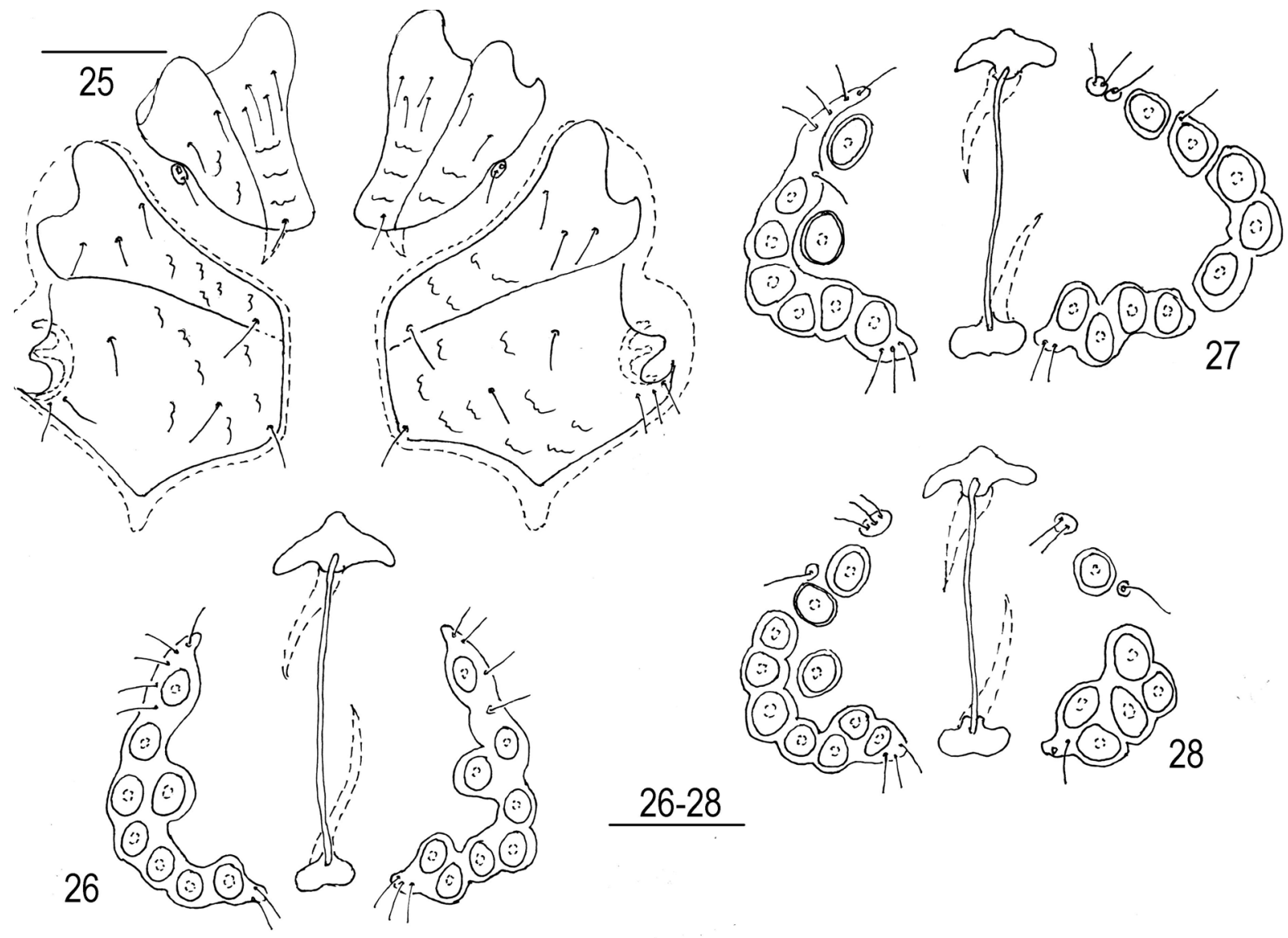

Figs. 25-28. Piona nodata (Müller, 1781), female: 25-coxal plates; 26-28-genital field. Scale bars $200 \mu \mathrm{m}$ (25), $100 \mu \mathrm{m}(26-28)$.

Figs. 3-5 (with concave anterior margin); basal segment of chelicera with reticulation (without reticulation); P-3 without distoventral projection (with distoventral projections). Therefore, the larva described under the name $P$. nodata (Wainstein 1980) probably belongs to another species.

The females of $P$. nodata produce small and large eggs from which small and large larvae develop, respectively (Böttger 1962). Small larvae require hosts, larger larvae may develop to nymphal stages without parasitism (Böttger 1962, Smith 1998). All Russian investigated larvae of $P$. nodata developed to nymphal stages without parasitism.

The larva of $P$. nodata is similar to the larva $P$. nodatella Tuzovskij, 2015, from which it is easily distinguishable by the structure of the pedipalps and III-Legs. P-4 in the larva P. nodata with three setae (Fig. 9), and III-Leg-2 with single heavy seta (Fig. 12). In contrast, in the larva P. nodatella P-4 with two setae, and III-Leg-2 with two heavy setae (Tuzovskij 2017). The larvae of $P$. nodatella did not develop to nymphal stages without parasitism in laboratory conditions.

Sokolow $(1928,1940)$ described Piona nodata var. lacerata based on different acetabular plates in the female only. K.O. Viets (1987) regarded it as a separate species ( $P$. lacerata). The acetabular plates in the female $P$. lacerata are divided anteriorly on some asymmetric fragments, bearing acetabulum (a) and genital seta (e) which are situated on soft integument. I collected the females of $P$. nodata with normal (Fig. 26) and divided acetabular plates (Figs. 27-28) together in all the named regions of Russia. I have not found out any distinctions in the morphometric data in the females and males of both species. Thus, Piona lacerata should be considered as a junior synonym of $P$. nodata.

\section{ACKNOWLEDGEMENTS}

The author expresses sincere gratitude to anonymous referees for reviewing the manuscript.

\section{REFERENCES}

Gerecke, R., Gledhill, T., Pešić, V. and Smit, H. 2016. 8. Acari: Hydrachnidia III. In: R. Gerecke (Ed.). Süßwasserfauna von Mitteleuropa, 7/2-3. Elsevier $\mathrm{CmbH}$. Akademischer Verlag Berlin Heidelberg, pp. 1-429. 
Lundblad, O. 1968. Die Hydracarinen Schwedens. III. Arkiv för Zoology, 21 (6): 1-633.

Smit, H., Gerecke, R., Pesic, V. and Gledhill, T. 2015. On the taxonomic state of water mite taxa (Acari: Hydrachnidia) described from the Palaearctic. Part 3. Hygrobatoidea and Arrenuroidea with new faunistic data. Zootaxa, 3981 (4): 542-552.

Smith, B.P. 1998. Loss of larval parasitism in parasitengonine mites. Experimental and Applied Acarology, 22 (4): 188-199.

Sokolow, I.I. 1928. Zur Kenntnis der Hydracarinenfauna von Buchara. Zoologische Jahrbücher, Abteilung, Systematik, 54 (5-6): 467-486.

Sokolow, I.I. 1940 Hydracarina—vodyanye kleshchi. Chast' I. Hydrachnellae. Fauna SSSR (novaya seriya No 20. Paukoobraznye, 5 (2) [Hydracarinathe aquatic mites. Part I. Hydrachnellae]. Publisher: Nauka, Moscow-Leningrad, 24 pp.+511. [In Russian]

Sparing, I. 1959. Die Larven der Hydrachnellae, ihre parasitische Entwicklung und ihre Systematik. Parasitologische Schriftenreihe, 10: 1-165.

Tuzovskij, P.V. 1987. Morfologiya i postembryonalnoye razvitiye vodyanikh kleshchey [Morphology and postembryonic development of water mites]. Nauka, Moscow, 172 pp. [In Russian]

Tuzovskij, P.V. 1990. Opredelitel'deutonymphs vodyanykh kleshchey [Key to deutonymphs of water mites]. Nauka, Moscow, 238 pp. [In Russian]

Tuzovsky P.V. 2015. A new water mite species of the genus Piona Koch (Acari: Hydrachnidia, Pionidae). Acarina, 23 (2): 156-160.

Tuzovskij P.V. 2017. Larval morphology of the water mite Piona nodatella Tuzovskij, 2015 (Acari: Hydrachnidia, Pionidae). Ecologica Montenegrina, 11:37-41.

Viets, K.O. 1978. Hydracarina. In: J. Illies (Ed.). Limnofauna Europaea. Stuttgart, G. Fischer, pp. 154-181.

Viets, K.O. 1987. Die Milben des Süßwassers (Hydrachnellae und Halacaridae [part.], Acari). II. Katalog. Sonderbände des Naturwissenschaftlichen Vereins Hamburg, 8: 1-1012.

Wainstein, B.A. 1976. The larvae and system of the water mites of the subfamily Pioninae (Hygrobatidae, Acariformes). Trudy Instituta Biologii Vnutrennikh Vod, 34: 29-69. [In Russian]

Wainstein, B.A. 1980. Opredelitel'lichinok vodyanykh kleshchey [Key to water mite larvae]. Leningrad, Nauka, 238 pp. [In Russian] 